\title{
Studies on the Cell Walls of Pseudomonas Species Resistant to Ethylenediaminetetra-acetic Acid
}

\author{
BY S. G. WILKINSON \\ Department of Chemistry, University of Hull
}

(Accepted for publication 26 June 1968)

\begin{abstract}
SUMMARY
Cell walls were prepared from various species of the genus Pseudomonas which are resistant to ethylenediaminetetra-acetic acid (EDTA). The cell walls were analysed and comparisons made with the walls of EDTA-sensitive pseudomonads. The walls had none of the structural features which appeared to characterize EDTA-sensitive pseudomonads. Lipopolysaccharide was not extracted from the walls of resistant organisms by EDTA at $\mathrm{pH} 9 \cdot 2$. The wall of $\boldsymbol{P}$. iodinum contained almost no lipid or protein but consisted mainly of glycosaminopeptide and material which resembled a teichoic acid. It is proposed that this organism be removed from the genus Pseudomonas. The walls of $P$. diminuta, $P$. maltophilia, $P$. pavonacea and $P$. rubescens had compositions broadly characteristic of Gram-negative bacteria. The four species are not obviously related. Glycolipids were present in the walls of $P$. diminuta, $P$. maltophilia and $P$. rubescens. An ornithine-containing lipid was isolated from $P$. rubescens and partly characterized. A small amount of this lipid was also present in $P$. maltophilia. The wall of $P$. maltophilia was distinctive in its wide range of monosaccharide components, including an unidentified neutral sugar of high mobility on paper chromatograms.
\end{abstract}

\section{INTRODUCTION}

Ethylenediaminetetra-acetic acid (EDTA) has a toxic effect on Pseudomonas aeruginosa (MacGregor \& Elliker, 1958; Gray \& Wilkinson, I965a; Eagon \& Carson, 1965; Wilkinson, 1967), apparently the result of a lytic action by it on the cell wall of the organism (Gray \& Wilkinson, 1965a, b; Eagon \& Carson, 1965). A correlation has been found between bactericidal activity and chelate stability constants for polyaminocarboxylic acids related to EDTA, which indicated that chelation was involved in the toxic action of these compounds (Gray \& Wilkinson, 1965a). The structural importance of multivalent metal cations in the wall of $P$. aeruginosa has been confirmed (Eagon \& Carson, 1965; Asbell \& Eagon, I966a, b). Treatment of the bacteria with EDTA caused these cations to become soluble (Eagon \& Carson, 1965) and also of the lipopolysaccharide component of the cell wall (Gray \& Wilkinson, 1965 b). Although EDTA has been found to extract lipopolysaccharide from Escherichia coli, the bacteria remained viable under the conditions used (Leive, 1965). Except when used in conjunction with organic cations (Wolin, 1966; Goldschmidt \& Wyss, 1967; Voss, 1967), EDTA does not seem to be highly toxic for Gram-negative bacteria other than pseudomonads (Gray \& Wilkinson, 1965a; Wilkinson, 1967). This hypersensitivity to EDTA might prove to be a useful characteristic in the taxonomy of the pseudomonads (Shively \& Hartsell, 1964; Wilkinson, 1967). 
In a survey of various pseudomonads (Wilkinson, 1967), only strains of the following species were found to be resistant to EDTA: Pseudomonas diminuta, P. geniculata, $P$. iodinum, $P$. maltophilia, $P$. pavonacea, $P$. rubescens. The inclusion of these organisms in the genus Pseudomonas has been considered doubtful by other workers who used different criteria. The cell walls of the EDTA-sensitive organisms $P$. aeruginosa and $P$. alcaligenes (originally described as Alcaligenes faecalis) are characterized by a relatively high content of phosphorus and have certain monosaccharide components in common, including glucose, rhamnose, glucosamine and galactosamine (Gray \& Wilkinson, $1965 b$ ). These sugars are present in the lipopolysaccharide fractions of the walls (Clarke, Gray \& Reaveley, 1967; B. A. Key, G. W. Gray \& S. G. Wilkinson, unpublished observations). It was therefore decided to prepare and analyse cell walls of EDTA-resistant pseudomonads in order to verify this description of them, and in order to examine their relationship to EDTA-sensitive pseudomonads.

\section{METHODS}

Preparation of cell walls. Cell walls were prepared from Pseudomonas diminuta (NCTC 8545), P. maltophilia (NCTC 10257), $P$. iodinum (NCTC 9742), P. pavonacea (NCIB 9395) and $P$. rubescens (NCIB 8768). Attempts to prepare walls from $P$. geniculata (NCIB 9428) were unsuccessful as the aggregated bacteria obtained were resistant to the disintegration technique used. Organisms were grown for $24 \mathrm{hr}$ on nutrient agar (Oxoid) at $25^{\circ}$ ( $37^{\circ}$ for $P$. iodinum and $P$. maltophilia). Suspensions of washed bacteria were cooled to $0^{\circ}$ and shaken for 3 min. with acid-washed ballotini beads (no. I2) in an MSK Homogeniser (B. Braun, Melsungen, Germany). The temperature was kept below $5^{\circ}$ by intermittent cooling with liquid $\mathrm{CO}_{2}$. After removal of beads by filtration, the crude walls were collected and purified as described previously (Gray \& Wilkinson, $1965 a$ ). After freeze-drying the walls were stored at $4^{\circ}$ and were freshly dried in vacuum over $\mathrm{P}_{2} \mathrm{O}_{5}$ before quantitative analysis.

General methods. Samples of walls were examined with a Siemens Elmiskope Ia electron microscope as preparations on carbon films and were shadowed with gold palladium at a $45^{\circ}$ angle. Equipment for high and low voltage paper electrophoresis was obtained from the Shandon Scientific Co. Ltd. A Perkin-Elmer F I I Gas Chromatograph fitted with a flame ionization detector was used for gas-liquid chromatography. Infrared spectra were recorded by using a Unicam SP. 200 spectrophotometer; samples were normally dispersed in discs of $\mathrm{KCl}$.

Solvents for paper chromatography. The following solvent systems were used for paper chromatography of water-soluble products obtained after hydrolysis of cell walls and wall fractions: $I$, the upper phase of ethyl acetate + pyridine + water $(5+2+5$, by vol.); II, the upper phase of $n$-butanol + ethanol + water + aq. ammonia sp.gr. $0 \cdot 88$ $(40+10+49+\mathrm{I}$, by vol.); III, the upper phase of ethyl acetate + acetic acid + water $(3+\mathrm{I}+3$, by vol. $) ;$ IV, ethyl acetate + pyridine + water + acetic acid $(5+5+3+\mathrm{I}$, by vol; Fischer \& Nebel, I955); V, ethyl acetate + pyridine $+n$-butanol $+n$-butyric acid + water (IO+IO+5+I +5, by vol.; Mukerjee \& Ram, I964); VI, sec-butanol + 88\% formic acid + water ( $75+15+$ Io, by vol.); VII, phenol + water + aq. ammonia sp.gr. $0.88(80+20+\mathrm{I}$, by wt); VIII, $n$-butanol + ethanol + water $(4+\mathrm{I}+\mathrm{I}$, by vol. $)$; IX, isopropanol $+5 \%$ aq. boric acid ( $7+\mathrm{I}$, by vol.; Ikawa, Morrow \& Harney, 1966); $\mathrm{X}, n$-propanol + aq. ammonia sp.gr. $0 \cdot 88+$ water $(6+3+\mathrm{I}$, by vol. $) ; \mathrm{XI}$, isopropanol + 
aq. ammonia sp.gr. $0 \cdot 88+$ water $(7+\mathrm{I}+2$, by vol. $) ; \mathrm{XII}, n$-butanol + pyridine + water $(6+4+3$, by vol.); XIII, ethyl methyl ketone + acetic acid + water $(8+2+\mathrm{I}$, by vol. $)$; XIV, $n$-butanol + propionic acid + water (I4I + 7I + I00, by vol.; Maruo \& Benson, 1959); XV, $n$-butanol + acetic acid + water $(5+\mathrm{I}+2$, by vol. $)$.

Quantitative analyses. Depending on the amount of material available, phosphorus was estimated by the method of Bartlett (1959) or by the method of Allen (1940). Nitrogen was estimated by nesslerization (Umbreit, Burris \& Stauffer, 1957) after digestion of samples for $\mathrm{I} 6 \mathrm{hr}$ with $\mathrm{H}_{2} \mathrm{SO}_{4}+\mathrm{CuSeO}_{3}$. Total carbohydrate was estimated by the method of Dubois et al. (1956) without prior hydrolysis of samples, and was expressed as glucose. Reactions with cysteine were used to estimate rhamnose (Dische \& Shettles, 1948) and aldoheptoses (Osborn, 1963). Cell walls were examined for the presence of 2-keto-3-deoxyaldonic acids as described by Osborn (1963): for the purpose of calibration $0.01 \mu$ mole of acid was taken to give an extinction of 0.2 (in a $\mathrm{I} \mathrm{cm}$. cell) at $548 \mathrm{~m} \mu$. Amino compounds in hydrolysates were estimated using a Technicon AutoAnalyser. Ornithine was estimated by the acid ninhydrin reaction using the reagent (b) described by Work (1957).

Identification of amino acids. Samples to be analysed were hydrolysed under nitrogen in sealed ampoules with $6 \mathrm{~N}-\mathrm{HCl}$ for $16 \mathrm{hr}$ at $105^{\circ}$. Insoluble material was removed by filtration through sintered glass (no. 4 porosity) and acid was removed by repeated drying in vacuum over $\mathrm{P}_{2} \mathrm{O}_{5}$ and $\mathrm{KOH}$. Amino acids in the hydrolysates were identified by ion-exchange chromatography by using the AutoAnalyser, by ascending twodimensional paper chromatography on Whatman no. 20 paper using the solvent systems VI followed by VII, and by two-dimensional thin-layer chromatography on silica gel $G$ (Merck) using the solvent systems chloroform + methanol $+17 \%$ (w/v) aq. ammonia $(2+2+\mathrm{I}$, by vol.) followed by phenol + water $(3+\mathrm{I}$, by $w t)$

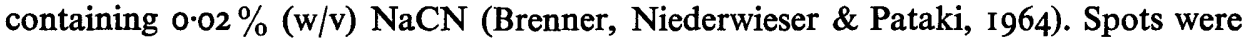
detected with ninhydrin. Ornithine was also identified by the spectrum of the product formed in the acid ninhydrin reaction, and by one-dimensional thin-layer chromatography on ether-washed layers of MN 300 cellulose (Macherey, Nagel \& Co., Düren, Germany) using the solvent systems phenol+water $(100+39$, by wt) and methanol + water + pyridine + conc. $\mathrm{HCl}(32+7+4+\mathrm{I}$, by vol.; Perkins \& Cummins, 1964).

Identification of amino sugars. Hydrolysates prepared for the analysis of amino acids or neutral sugars were sometimes examined for the presence of amino sugars. In more critical studies samples were hydrolysed for $3 \mathrm{hr}$ at $105^{\circ}$ with $4 \mathrm{~N}-\mathrm{HCl}$ and the hydrolysates were neutralized using Dowex 2 resin in the bicarbonate form. The hydrolysates were then passed down short columns of Dowex 50 resin (200-400 mesh) in the hydrogen form (Boas, 1953), and the resin was washed free from neutral solutes. Amino sugars were recovered from the resin by elution with $2 \mathrm{~N}-\mathrm{HCl}$ and the acid was removed by repeated drying in vacuum over $\mathrm{P}_{2} \mathrm{O}_{5}$ and $\mathrm{KOH}$ at room temperature. Amino sugars were identified by ion-exchange chromatography by using the AutoAnalyser. Paper chromatography was done on Whatman no. I paper using solvent systems IV and V (descending). Spots were detected using alkaline $\mathrm{AgNO}_{3}$ (Trevelyan, Proctor \& Harrison, 1950). Confirmation of glucosamine and galactosamine was obtained by ninhydrin degradation after one-dimensional chromatography in solvent system IV, followed by chromatography of the resulting pentoses in the second dimension using solvent system VIII (Stoffyn \& Jeanloz, 1954). For the 
identification of amino sugars by gas-liquid chromatography, their trimethylsilyl derivatives were prepared by dissolving samples containing about $200 \mu \mathrm{g}$. total amino sugar in dry $N, N$-dimethylformamide $(60 \mu 1$.) and adding bis-(trimethylsilyl)acetamide $(40 \mu \mathrm{l}$.). After about $\mathrm{I} \mathrm{hr}$ at room temperature, samples were analysed using a column packed with $15 \%$ (w/w) Apiezon M on Chromosorb W (60-80 mesh) and operated at $225^{\circ}$ with a nitrogen flow rate of $27 \mathrm{ml} . / \mathrm{min}$.

Identification of sugars. Samples were hydrolysed for $2 \mathrm{hr}$ at $105^{\circ}$ with $2 \mathrm{~N}-\mathrm{HCl}$, and the hydrolysates neutralized with Dowex 2 resin in the bicarbonate form. When necessary, neutral sugars were separated from amino acids and amino sugars by passage of hydrolysates down cation-exchange columns as described above. Descending paper chromatography was done on Whatman no. I paper, usually using the solvent systems I, II, III and IV, detecting spots with alkaline $\mathrm{AgNO}_{3}$, aniline hydrogen phthalate and periodate-Schiff's reagents (Baddiley, Buchanan, Handschumacher \& Prescott, 1956). For special purposes the solvent systems VIII, IX, XII, XIII and XV and the detection reagents periodate-thiobarbiturate (Warren, 1960; Cynkin \& Ashwell, 1960), p-anisidine hydrochloride, naphthoresorcinol (Bryson \& Mitchell, 195I), periodate- $p$-nitroaniline and $p$ - $N, N$-dimethylaminobenzaldehyde- $\mathrm{HCl}$ (Edward \& Waldron, 1952) were used. When necessary sugars were eluted from chromatograms and their identities confirmed by further tests. Xylose was conclusively differentiated from lyxose by low voltage electrophoresis at $0.4 \mathrm{~mA} / \mathrm{cm}$. for $4 \mathrm{hr}$ in

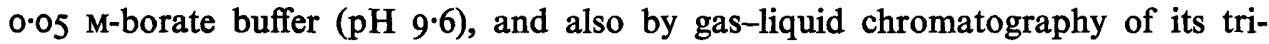
methylsilyl derivative (Sweeley, Bentley, Makita \& Wells, 1963). Chromatography was done using a column of $20 \%$ (w/w) silicone SE-30 on Chromosorb W (60-80 mesh) operated at $175^{\circ}$ with a nitrogen flow rate of $20 \mathrm{ml} . / \mathrm{min}$.

Extraction of loosely bound lipids. Samples (10-25 mg.) of walls were stirred under nitrogen with chloroform + methanol ( $2+\mathrm{I}$, by vol.; $5 \mathrm{ml}$.) for $2 \mathrm{hr}$ at room temperature. Insoluble residues were collected by filtration of the extract through sintered glass (no. 4 porosity) and were washed with further solvent (Io ml.). The combined extracts and washings were collected in tared weighing bottles and the solvent was removed by evaporation under a stream of nitrogen at room temperature. The lipid residues were dried overnight in vacuum over $\mathrm{P}_{2} \mathrm{O}_{5}$ and, after weighing, were dissolved in chloroform + methanol and stored under nitrogen at $-20^{\circ}$. Further extractions on a larger scale were made with walls of Pseudomonas diminuta, $P$. iodinum and $P$. maltophilia, and with freeze-dried whole $P$. rubescens organisms.

Thin-layer chromatography of lipids. For the identification of phospholipids and other polar lipids, samples were normally examined by chromatography on silica gel $\mathrm{G}$ using chloroform + methanol + water $(65+25+4$, by vol.). Further information was obtained with the solvent system chloroform + methanol $+7 \mathrm{~N}$-aq. ammonia $(65+25+$ 4, by vol.; Nichols, 1964), with silica gel H and the Systems I (two-step) and III of Skipski, Barclay, Reichman \& Good (1967), and with basic silica gel H and chloroform + methanol + acetic acid + water $(50+25+8+4$, by vol.; Skipski, Peterson, Sanders \& Barclay, 1963). Spots were detected using iodine vapour, ninhydrin, periodate-Schiff's reagents and reagents for phosphorus (Wagner, Hörhammer \& Wolff, I96r ; Dittmer \& Lester, 1964). Samples were also examined for the presence of neutral lipids and fatty acids by the method of Skipski, Smolowe, Sullivan \& Barclay (1965); spots were detected by iodine vapour and by a modified $\mathrm{H}_{2} \mathrm{SO}_{4}$ spray (Zimiński \& Borowski, 1966). 
Fractionation of lipids from walls of Pseudomonas diminuta. A sample of total lipids ( $17.89 \mathrm{mg}$.) was dissolved in chloroform $(4 \mathrm{ml}$.) and the solution was clarified by filtration through sintered glass (no. 4 porosity). Ether ( $16 \mathrm{ml}$.) was added to the filtrate and the flocculent white precipitate which developed on standing was collected by filtration, washed with ether and redissolved in chloroform. The weights of lipid soluble and insoluble in ethereal chloroform were $14.4 \mathrm{I}$ and $2.87 \mathrm{mg}$., respectively. The composition of the soluble fraction was studied by thin-layer chromatography. Glycolipids present were isolated by elution from appropriate zones of silica and were partly characterized as described elsewhere (Wilkinson, 1968).

Fractionation of lipids from walls of Pseudomonas maltophilia. A sample of total lipids (26 mg.) was fractionated on a column of silicic acid (Mallinckrodt, 100 mesh; $7 \mathrm{~g}$.) packed in chloroform, by stepwise elution with chloroform (I00 ml.) and 5, 10, 20 and $33 \%(\mathrm{v} / \mathrm{v})$ solutions of methanol in chloroform $(75 \mathrm{ml}$. each). Fractions of $5 \mathrm{ml}$. were collected and samples (I \%) were screened by thin-layer chromatography. Samples of appropriately bulked fractions were retained and the remaining material was recombined and subjected to further chromatography on a similar column of different silicic acid (Baker's Analysed Reagent) using the same scheme of elution. Fractions were again screened by thin-layer chromatography and also by identification of the products formed on mild alkaline hydrolysis of the phospholipids. The lipid samples (containing up to $300 \mu \mathrm{g}$. phosphorus) were dissolved in chloroform (I ml.) and $0.2 \mathrm{~N}$-methanolic $\mathrm{KOH}$ ( $\mathrm{I} \mathrm{ml}$.) was added. After incubation of the mixture for $20 \mathrm{~min}$. at $37^{\circ}$, ethyl formate $(0.05 \mathrm{ml}$.) was added and incubation was continued for $5 \mathrm{~min}$. Chloroform ( $\mathrm{I} \mathrm{ml}$.) and water ( $\mathrm{I} \mathrm{ml}$.) were added and the layers were thoroughly mixed. After centrifugation the aqueous layer was withdrawn and the chloroform layer was further extracted with water $(2 \times 1 \mathrm{ml}$.). With the total phospholipids from $P$. maltophilia only $\mathrm{I} \cdot 3 \%$ of the initial phosphorus remained in the chloroform layer. The combined aqueous extracts were passed down a column of Dowex 50 in the ammonium form and the eluate was dried in vacuum over $\mathrm{P}_{2} \mathrm{O}_{5}$. The residue was examined by paper chromatography using solvent systems X and XIV (ascending) on Whatman no. 54I paper and system XI (descending) on Whatman no. I paper. Chromatograms were sprayed with ninhydrin, periodate-Schiff's reagents and the reagent of Hanes \& Isherwood (1949) for phosphorus. The water-soluble products were also identified by high voltage electrophoresis ( $5000 \mathrm{~V}$ for I hr) on Whatman no. I

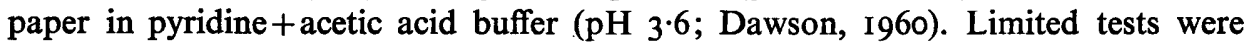
applied to column fractions containing glycolipids and an ornithine-containing lipid also found in $P$. rubescens (see below).

Fractionation of lipids from whole Pseudomonas rubescens organisms. The major ninhydrin-positive lipid in the cell wall of $P$. rubescens contained ornithine but no phosphorus. To obtain larger amounts of this material, lipids were extracted from whole organisms. The total lipids ( $95 \mathrm{mg} ., 8 \cdot 2 \%$ of dry weight) were fractionated on a column of silicic acid (Mallinckrodt) as described for P. maltophilia. A mixture of two glycolipids also present in the cell wall was eluted with $5 \%(\mathrm{v} / \mathrm{v})$ methanol in chloroform and was studied separately (Wilkinson, 1968). The lipid containing ornithine was eluted in late fractions of $10 \%(\mathrm{v} / \mathrm{v})$ methanol and in $20 \%(\mathrm{v} / \mathrm{v})$ methanol in chloroform. The trace of phosphatidylglycerol and most of the phosphatidylethanolamine present in the combined fractions were removed by chromatography on a column $(12 \mathrm{~cm} . \times 2 \mathrm{~cm}$.) of DEAE-cellulose (Whatman DE 23) in the acetate form (Rouser, Kritchevsky, Heller 
\& Lieber, 1963). The crude ornithine-containing lipid was eluted using $12.5 \%(\mathrm{v} / \mathrm{v})$ methanol in chloroform (350 ml.). After repeat chromatography on a second column of DEAE-cellulose the lipid (I8.9 mg., $0.53 \%$ phosphorus) still contained about $10 \%$ phosphatidylethanolamine. The mixture $(7 \mathrm{mg}$.) was subjected to mild alkaline hydrolysis (Gorchien, 1964) during which all of the phospholipid, but only part of the ornithinecontaining lipid, was degraded. The intact lipid and its ninhydrin-positive degradation product were separated by chromatography on silicic acid and were purified by preparative thin-layer chromatography on silica gel $G$ using chloroform + methanol + water $(65+25+4$, by vol.). Zones of silica containing the lipids were transferred to small columns and the lipids were eluted using solutions of increasing concentration of methanol in chloroform. After removal of the solvents using a rotary evaporator, the residues were dissolved in chloroform + methanol $(2+\mathrm{I}$, by vol., $4 \mathrm{ml}$.) and the solutions were washed with water (I ml.) to remove non-lipid contaminants (Duthie \& Patton, 1965). The final yields of the intact lipid and its degradation product were 2.12 and $0.57 \mathrm{mg}$., respectively. A sample of the intact lipid was hydrolysed under nitrogen with $2 \mathrm{~N}-\mathrm{HCl}$ (I ml.) for $3 \mathrm{hr}$ at $105^{\circ}$ and the hydrolysate was extracted with light petroleum (b.p. $60-80^{\circ} ; 6 \times \mathrm{I}$ ml.). Fatty acids present in the extract were methylated using $\mathrm{BF}_{3}$-methanol (Morrison \& Smith, 1964). The methyl esters were examined by gas-liquid chromatography using columns of $10 \%(\mathrm{w} / \mathrm{w})$ poly-diethylene glycol succinate on Chromosorb W (80-100 mesh) and 20\% (w/w) Apiezon L on Chromosorb $P$ (60-80 mesh). Oven temperatures were $160^{\circ}$ and $220^{\circ}$ and nitrogen flow rates were 26 and $31 \mathrm{ml}$. $/ \mathrm{min}$. for the polar and non-polar columns, respectively.

A further sample of the intact lipid was reacted with 2,4-dinitrofluorobenzene (Wheeldon \& Collins, 1957) and the DNP-lipid was hydrolysed with $6 \mathrm{~N}-\mathrm{HCl}$ for $4 \mathrm{hr}$ at $105^{\circ}$. The hydrolysate was extracted with ether $(6 \times \mathrm{I} \mathrm{ml}$.) and the aqueous layer was dried in vacuo over $\mathrm{P}_{2} \mathrm{O}_{5}$ and $\mathrm{KOH}$. The residue was dissolved in $n$-butanol +ethyl acetate ( $I+I$, by vol.) and examined by thin-layer chromatography on silica gel $G$ using the solvent systems $n$-propanol + aq. ammonia sp.gr. $0.88(7+3$ by vol.; Brenner, Niederwieser \& Pataki, I96I), the upper phase of $n$-butanol+acetic acid + water $(4+\mathrm{I}+5$, by vol. $)$ and 2 -chloroethanol + toluene + pyridine $+20 \%(\mathrm{w} / \mathrm{v}) \mathrm{aq}$. ammonia (10 $+7+3+2$, by vol.; Pataki, 1967).

Extraction of cell walls of Pseudomonas iodinum with trichloroacetic acid. Lipid-free walls (202 mg.) of $P$. iodinum were stirred for $24 \mathrm{hr}$ at $4^{\circ}$ with $10 \%$ (w/v) aq. trichloroacetic acid $(25 \mathrm{ml}$.) Insoluble material was collected by centrifugation, extracted for $48 \mathrm{hr}$ with further solvent $(25 \mathrm{ml}$.), washed four times with deionized water and freeze-dried (yield $119 \mathrm{mg}$.). Both extracts were clarified by filtration through glass sinters (no. 4 porosity) and each was added to acetone $\left(100 \mathrm{ml}\right.$.) at $4^{\circ}$. As very little precipitate formed on standing for 4 days at $4^{\circ}$, most of the acetone was removed from the combined extracts at $20^{\circ}$ using a rotary evaporator. The aqueous residue was made to $100 \mathrm{ml}$. and samples were taken for phosphorus analysis. The remaining solution was extracted with $n$-butyl acetate $(6 \times$ Ioo $\mathrm{ml}$.; Young, 1964), neutralized by the addition of 2 drops of dil. aq. ammonia and freeze-dried. The white, deliquescent solid (I 19 mg.) was analysed for phosphorus and sugars.

As the weight of the crude extract exceeded the loss in weight of the cell walls (83 $\mathrm{mg}$.), the remaining material was dissolved in water ( $\mathrm{IO} \mathrm{ml}$.) and was dialysed for 3 days at $4^{\circ}$ against deionized water $(21$.$) , with external stirring and four changes of$ water. During dialysis $78 \%$ of the weight of material and $30 \%$ of the total phosphorus 
passed into the diffusate. The non-diffusable residue was dried down as a colourless glass $(20 \mathrm{mg}$.). The mobility of phosphorus-containing material on low voltage $(0.6 \mathrm{~mA} / \mathrm{cm}$. for $3 \mathrm{hr})$ and high voltage $(5000 \mathrm{~V}$ for $\mathrm{I} .5 \mathrm{hr}$ ) electrophoresis in pyridine +

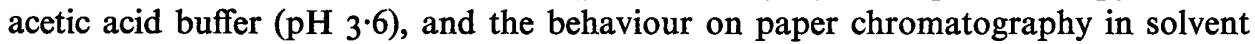
system $\mathrm{X}$ were studied. Organic phosphates formed on hydrolysis with $2 \mathrm{~N}-\mathrm{HCl}$ for $3 \mathrm{hr}$ at $105^{\circ}$ were eluted from a paper chromatogram run in solvent system $\mathrm{X}$, and were incubated under toluene with alkaline phosphatase (Sigma Chemical Co.) at I mg./ml. in 0.05 M-ammonium carbonate buffer $\left(\mathrm{pH} \mathrm{9.3)}\right.$ for $\mathrm{I} 6 \mathrm{hr}$ at $37^{\circ}$. After drying down, the residue was examined for sugars and polyols by paper chromatography.

Extraction of cell walls with EDTA. Suspensions of cell walls $(4 \mathrm{mg} . / \mathrm{ml}$.) in 0.05 M-borate buffer ( $\mathrm{pH} \mathrm{9.2)} \mathrm{were} \mathrm{treated} \mathrm{with} \mathrm{equal} \mathrm{volumes} \mathrm{of} 6.8 \mathrm{~mm}$-EDTA in the buffer or of buffer alone. After $\mathrm{I} \mathrm{hr}$ at $20^{\circ}$ insoluble residues were deposited by centrifugation for I hr at $10,000 \mathrm{rev} . / \mathrm{min}$. and the supernatant fluids were analysed for phosphorus (Gray \& Wilkinson, 1965b).

\section{RESULTS}

\section{General observations}

Although the quantitative results tabulated below relate only to single batches of cell walls from each bacterium, analyses on different batches were qualitatively and, except in the case of Pseudomonas iodinum, quantitatively reproduced. The nature of the analytical variations for $P$. iodinum is described in a later section. Only in preparations from $P$. diminuta was there evidence from electron micrographs of significant contamination of the walls by cytoplasmic or other materials. The preparations from $P$. diminuta contained a small amount of material similar to that found to contaminate wall preparations from Rhizobium trifolii (Vincent, Humphrey \& North, 1962). The possibility that this material was $\beta$-hydroxybutyrate polymer was borne out by subsequent studies on lipids extracted from the preparations. The cell walls from $P$. iodinum differed notably from the others in being pure white and in the ease with which clean preparations were obtained by washing procedures alone. Although treatment with enzymes was included in the purification scheme, this step appeared to be unnecessary with $P$. iodinum. These properties and the smooth, clean appearance of the walls in electron micrographs are usually more characteristic of Gram-positive than of Gram-negative bacteria. The infrared spectrum of the walls of $P$. iodinum (Fig. I) also differed appreciably from those of the cell walls of Gram-negative bacteria (Gray \& Wilkinson, $1965 b$ ). The relatively weak absorptions at about $2900 \mathrm{~cm}^{-1}$ (associated with C-H stretching vibrations) and at 1655 and $1550 \mathrm{~cm}^{-1}$ (amide I and II bands) indicate that the cell walls contain little lipid or protein. The infrared spectra of the other cell walls studied are dominated by absorption bands from protein components. The spectrum of the walls of $P$. diminuta also contains an unusually strong band at $1730 \mathrm{~cm}^{-1}$ (probably ester carbonyl absorption). None of the spectra contain the minor absorption band at $928 \mathrm{~cm}^{-1}$ present in the spectra of the EDTAsensitive organisms $P$. aeruginosa and $P$. alcaligenes (Gray \& Wilkinson, $1965 b$ ). 


\section{General analyses}

The results of quantitative analyses on the cell walls are summarized in Table I. It can be seen that the walls of Pseudomonas iodinum contained essentially no lipid, while the low nitrogen analysis was also consistent with a low content of protein as inferred from the infrared spectrum. The phosphorus content of the cell walls of $\boldsymbol{P}$. iodinum was notably high while that of the walls of $\boldsymbol{P}$. diminuta was notably low.

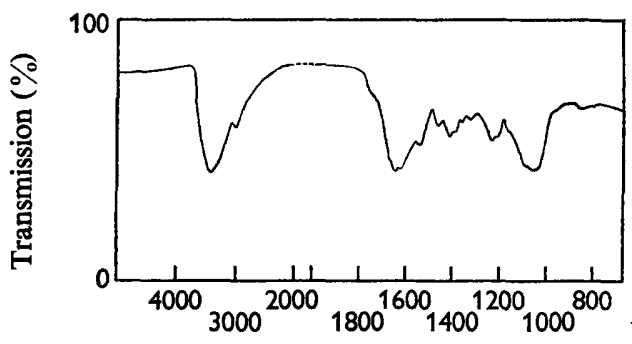

Wave-number $\left(\mathrm{cm} .^{-1}\right)$

Fig. I

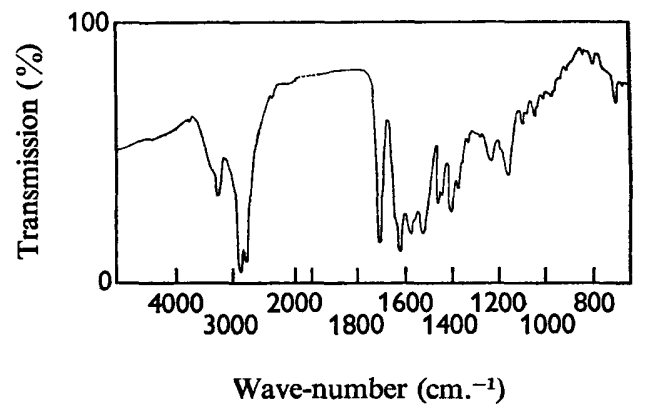

Fig. 2

Fig. I. Infrared spectrum of cell walls of Pseudomonas iodinum.

Fig. 2. Infrared spectrum of ornithine-containing lipid from Pseudomonas rubescens. The lipid was dispersed in a $\mathrm{KCl}$ disc.

\section{Amino acid composition}

It was confirmed by paper, thin-layer and ion-exchange chromatography that the walls of Pseudomonas diminuta, P. maltophilia, $P$. pavonacea, and $P$. rubescens contained a wide range of amino acids in amounts expected for protein-containing materials. In the walls of $P$. iodinum only alanine, glutamic acid and $\alpha, \epsilon$-diaminopimelic acid (together with amino sugars) were present in major amounts. The results of quantitative analyses of amino compounds are given in Table 2 ; nitrogen recoveries were in the range $93-105 \%$.

\section{Amino sugar components}

The glycosaminopeptide components muramic acid and glucosamine were present in each of the wall preparations. The results of quantitative analyses (uncorrected for destruction of amino sugars during hydrolysis) are included in Table 2. Galactosamine was a minor component of the wall of Pseudomonas iodinum and was not detected in the walls of the other bacteria. Direct preparation of the trimethylsilyl derivatives of the three amino sugars, without prior $N$-acetylation by the method described, was found to be more reliable than other methods reported (Kärkkäinen, Lehtonen \& Nikkari, 1965; Radhakrishnamurthy, Dalferes \& Berenson, I966). By using a column of Apiezon $M$ two peaks were found for each amino sugar. Retention times relative to that of the derivative from $\alpha$-glucopyranose were: glucosamine, 0.99 and $\mathrm{I} \cdot 22$; galactosamine, 0.76 and 0.86 ; muramic acid, 2.32 and 2.71 . No interference from amino acids present in the hydrolysates was found under the conditions used. 
Table I. General analyses of cell walls of some Pseudomonas species

\begin{tabular}{|c|c|c|c|c|c|}
\hline Species & $\begin{array}{c}\text { Nitrogen } \\
(\%)\end{array}$ & $\begin{array}{c}\text { Phosphorus } \\
(\%)\end{array}$ & $\begin{array}{c}\text { Carbo- } \\
\text { hydrate* } \\
(\%)\end{array}$ & $\begin{array}{l}\text { 2-Keto- } \\
\text { 3-deoxy- } \\
\text { aldonic } \\
\text { acid } \dagger \\
(\%)\end{array}$ & $\underset{(\%)}{\text { Lipid }}$ \\
\hline$P$. diminuta & $8 \cdot 53$ & 0.15 & $14 \cdot 3$ & I.05 & $28 \cdot 2$ \\
\hline$P$. iodinum & $5 \cdot 10$ & 3.07 & $11 \cdot 3$ & 2.04 & 0.4 \\
\hline P. maltophilia & $9 \cdot 74$ & 0.79 & $20 \cdot 8$ & 0.22 & $12 \cdot 7$ \\
\hline P. pavonacea & $8 \cdot 29$ & 1.09 & 5.4 & I.OI & I $I \cdot I$ \\
\hline P. rubescens & $8 \cdot 36$ & 0.96 & $I I \cdot I$ & 0 & $23 \cdot 7$ \\
\hline
\end{tabular}

* Expressed as glucose and corrected for controls.

+ Expressed as 2-keto-3-deoxyoctonic acid.

Table 2. Analyses of amino compounds present in cell walls of some Pseudomonas species

Cell walls were hydrolysed for $16 \mathrm{hr}$ at $105^{\circ}$ with $6 \mathrm{~N}-\mathrm{HCl}$. Results are calculated for residues of amino compounds and are not corrected for destruction or slow release during hydrolysis.

\begin{tabular}{|c|c|c|c|c|c|}
\hline \multirow{2}{*}{ Compound } & \multicolumn{5}{|c|}{ Organism } \\
\hline & $P$. diminuta & \multicolumn{2}{|c|}{$\begin{array}{r}P . \text { iodinum } P \text {. maltophilia } \\
\text { Component of wall }\end{array}$} & $\begin{array}{l}\text { P. pavonacea } \\
(\%)\end{array}$ & $P$. rubescens \\
\hline Aspartic acid & 5.54 & 0.33 & 6.51 & 5.04 & $6 \cdot 43$ \\
\hline Threonine & 3.04 & 0.15 & $2 \cdot 44$ & $2 \cdot 22$ & $2 \cdot 89$ \\
\hline Serine & $2 \cdot 50$ & 0.30 & $2 \cdot 70$ & $I \cdot 83$ & $2 \cdot 95$ \\
\hline Glutamic acid & $5 \cdot 43$ & $6 \cdot 82$ & $6 \cdot 04$ & $7 \cdot 02$ & $5 \cdot 14$ \\
\hline Proline & $2 \cdot 48$ & trace & 2.45 & $I \cdot 15$ & $1 \cdot 18$ \\
\hline Glycine & $2 \cdot 69$ & 0.19 & 2.45 & $1 \cdot 60$ & $2 \cdot 10$ \\
\hline Alanine & $5 \cdot 00$ & $7 \cdot 33$ & 4.43 & $5 \cdot 61$ & 3.52 \\
\hline Valine & $2 \cdot 79$ & 0.15 & $2 \cdot 62$ & $1 \cdot 88$ & $2 \cdot 50$ \\
\hline Cystine & 0.13 & trace & 0.21 & $0 \cdot 10$ & 0.10 \\
\hline Methionine & 0.64 & trace & 0.74 & 0.43 & $1 \cdot 14$ \\
\hline Isoleucine & $I \cdot 50$ & 0.05 & $1 \cdot 56$ & $1 \cdot 36$ & $I \cdot 46$ \\
\hline Leucine & $3 \cdot 33$ & 0.09 & $3 \cdot 66$ & $2 \cdot 80$ & $4 \cdot 03$ \\
\hline Tyrosine & $2 \cdot 29$ & 0.12 & $2 \cdot 74$ & $I \cdot 97$ & $2 \cdot 68$ \\
\hline Phenylalanine & $2 \cdot 66$ & 0.07 & $2 \cdot 65$ & $1 \cdot 68$ & $2 \cdot 92$ \\
\hline $\begin{array}{l}\text { Diaminopimelic } \\
\text { acid }\end{array}$ & $1 \cdot 83$ & $8 \cdot 29$ & $I \cdot 9 I$ & 4.05 & 0.86 \\
\hline Ornithine & 0.24 & 0.15 & 0.09 & 0.23 & $I \cdot 90$ \\
\hline Lysine & $1 \cdot 33$ & 0.39 & $2 \cdot 38$ & 1.87 & $2 \cdot 83$ \\
\hline Histidine & 0.66 & 0.12 & 0.65 & 0.49 & 0.49 \\
\hline Arginine & 3.43 & $0 \cdot 16$ & $3 \cdot 70$ & $1 \cdot 58$ & $1 \cdot 89$ \\
\hline Glucosamine & 1.17 & 6.02 & 2.03 & 3.85 & $1 \cdot 51$ \\
\hline Galactosamine & 0 & 0.64 & 0 & 0 & 0 \\
\hline Muramic acid & $1 \cdot 49$ & $7 \cdot 12$ & $I \cdot 46$ & 3.91 & 0.50 \\
\hline Ethanolamine & 0 & 0 & 0.14 & $0 \cdot 26$ & $0 \cdot 17$ \\
\hline
\end{tabular}

\section{Sugar components}

The monosaccharide components of the walls (other than amino sugars) whose presence was confirmed by chromatography are given in Table 3, which also indicates the amount of each sugar relative to other sugars in the same cell wall, as judged by the intensities of spots on paper chromatograms. In addition to the monosaccharides listed, hexuronic acids have been detected in the wall lipids of Pseudomonas diminuta, 
$P$. maltophilia and $P$. rubescens (Wilkinson, 1968). Estimates for total carbohydrate and for 2-keto-3-deoxyaldonic acids (Table I), and for rhamnose in the wall of $P$. maltophilia (I6.4\%), were made by colorimetric methods. In the thiobarbiturate test for 2-keto-3-deoxyaldonic acids the absorption peaks produced were as expected for $P$. diminuta $(549 \mathrm{~m} \mu), P$. iodinum $(548 \mathrm{~m} \mu)$ and $P$. pavonacea $(548 \mathrm{~m} \mu)$. Under comparable conditions a weak absorption peak at $543 \mathrm{~m} \mu$ was obtained for $P$. maltophilia, while $P$. rubescens gave no obvious reaction. In the cysteine reaction for aldoheptoses none of the walls gave spectra containing significant peaks at about $505 \mathrm{~m} \mu$ (a minor peak at $507 \mathrm{~m} \mu$ for $P$. rubescens was also present in a control without added cysteine). By using the differential extinction (505 $\mathrm{m} \mu$ minus $545 \mathrm{~m} \mu$ ) given by Osborn (1963) for L-glycero-D-mannoheptose, apparent heptose contents were calculated for the walls of $P$. diminuta $(0.55 \%), P$. maltophilia $(0.93 \%)$ and $P$. rubescens $(\mathrm{I} \cdot 15 \%)$; results for $P$. iodinum and $P$. pavonacea were negligible. Confirmation of suspected heptoses was not attempted.

\section{Table 3. Monosaccharide components of cell walls of some Pseudomonas species}

\begin{tabular}{|c|c|c|c|c|c|}
\hline Component & $P$. diminuta & $P$. iodinum & P. maltophilia & $P$. pavonacea & $P$. rubescens \\
\hline Glucose & 5 & 5 & 3 & $\mathbf{I}$ & 5 \\
\hline Galactose & 2 & 3 & I & 5 & 2 \\
\hline Mannose & 3 & 0 & I & 0 & 0 \\
\hline Xylose & 0 & o & 2 & 0 & 0 \\
\hline Rhamnose & 0 & 0 & 10 & 0 & o \\
\hline Unknown & 0 & 0 & 2 & 0 & 0 \\
\hline
\end{tabular}

The unknown sugar present in the wall of Pseudomonas maltophilia could not be identified by paper chromatography. It was not adsorbed either by cation- or anionexchange resins and therefore appeared to be a neutral sugar. It appeared to be fairly rapidly released on acid hydrolysis of the walls (after $5 \mathrm{~min}$. at $100^{\circ}$ in $\mathrm{N}-\mathrm{HCl}$ only rhamnose was present in the hydrolysate in larger amount) and was not noticeably acid labile. It readily reduced alkaline $\mathrm{AgNO}_{3}$ and its colour reactions with aniline hydrogen phthalate, $p$-anisidine hydrochloride and naphthoresorcinol were the same as for the aldopentoses. No reaction was detected with periodate-Schiff's reagents, ninhydrin, thiobarbiturate reagents or reagents for deoxysugars (Edward \& Waldron, 1952) with amounts of sample which were readily detected by the preceding reagents. The $R_{\text {Rbamnose }}$ values of the compound on descending paper chromatography in various solvent systems were as follows I, I·I9; II, I·I9; III, I·4I; IV, I·I2; XII, I·I4; XIII, $\mathrm{I} \cdot 39 ; \mathrm{XV}, \mathrm{I} \cdot \mathrm{I} 7$. The compound was differentiated from the 3,6-dideoxyhexoses which occur in bacterial lipopolysaccharides by its relative stability to acids and by its reactions with aniline hydrogen phthalate and periodate-thiobarbiturate reagents (Westphal \& Lüderitz, 1960). If the compound is a derivative of an aldopentose its high mobility on chromatograms might be explained, for example, by the presence of an $O$-methyl substituent. 


\section{Lipid components}

The contents of the loosely bound lipids of the wall preparations are given in Table I. Phosphorus analyses of the lipids were:Pseudomonas diminuta, $0.21 \%$; P. maltophilia, $2 \cdot 34 \% ; P$. pavonacea, $2 \cdot 92 \% ; P$. rubescens, $0.69 \%$. The range of components in each of the lipid extracts, as revealed by thin-layer chromatography, is illustrated in Fig. 3. Some of the components could be identified by using a variety of solvent systems and spray reagents, but others required more detailed study.

Lipids from Pseudomonas diminuta. The total lipids from $P$. diminuta were separated into an ether-soluble fraction (83.4\%) and an ether-insoluble fraction (16.6\%). The latter fraction was obtained as a translucent plastic film on drying a solution in chloroform. The infrared spectrum of the film (pressed between $\mathrm{KBr}$ windows) closely resembled a reference spectrum of poly- $\beta$-hydroxybutyrate, although there was evidence for a small amount of additional ester material. The film was rolled into a capillary tube and its melting range determined as $167-169^{\circ}$. On stronger heating the liquid decomposed and colourless crystals (presumably crotonic acid) were formed in the cooler part of the tube. Thus the original wall preparation appeared to contain about $4.7 \%$ of poly- $\beta$-hydroxybutyrate. The polymer may correspond to the spot of highest $R_{F}$ value in Fig. 3 .

Of the ether-soluble lipids only two minor components contained phosphorus. The component having the higher $R_{F}$ value might have been phosphatidic acid, while the other phospholipid rapidly gave a purple colour with periodate-Schiff's reagents and was probably phosphatidylglycerol. Small amounts of free fatty acid and a series of unidentified ninhydrin-positive components were also present. As lipid extracts were not treated for the removal of non-lipid contaminants, the latter may be impurities. The major ether-soluble lipids (D 2 and D 6 in Fig. 3) were isolated by thin-layer chromatography and have been partly characterized as glycolipids containing glucose and a hexuronic acid (Wilkinson, 1968).

Lipids from Pseudomonas rubescens. Glycolipids were isolated from whole cells of $P$. rubescens and were present in the wall lipids of this organism ( $\mathrm{R}_{3}$ and $\mathrm{R} 7$ in Fig. 3). Small amounts of unidentified neutral lipids and fatty acids and a trace of phosphatidylglycerol were also present in the cell-wall extract, together with larger amounts of phosphatidylethanolamine and an unidentified, ninhydrin-positive phospholipid. Phosphatidylethanolamine was calculated from the ethanolamine content of the total lipid extract to constitute about $12 \%$ of the lipid and to account for about $77 \%$ of the lipid phosphorus. Although the shape and position of the spot for the unidentified phospholipid ( $\mathrm{R} 9$ in Fig. 3) resemble those of phosphatidylserine, it was readily differentiated from the latter compound using a basic plate and an acidic solvent system (Skipski et al. 1963). This lipid has not been studied further.

The major lipid in the wall of Pseudomonas rubescens reacted strongly with ninhydrin (although more slowly than did phosphatidylethanolamine) and did not contain phosphorus. It overlapped, or was barely separated from, phosphatidylethanolamine in all the solvent systems tried. In these respects it resembled the ornithinecontaining lipid recently shown to occur in a number of other bacteria (Lanéelle, Lanéelle \& Asselineau, 1963; Gorchein, 1964; Depinto, 1967). It was confirmed that the total lipids from the wall of $P$. rubescens contained about $8 \%$ ornithine. Virtually 
all of the ornithine present in the cell wall was removed by extraction with chloroform + methanol $(2+1$, by vol.).

A small amount of the ornithine-containing lipid was isolated from whole Pseudomonas rubescens organisms as described under Methods. The infrared spectrum of the purified lipid is given in Fig. 2. It contains absorption bands indicative of ester, amide and amino groups. No ester carbonyl absorption band was present in the spectrum of the partly degraded lipid isolated after alkaline hydrolysis, and absorption bands in the region $1500-1700 \mathrm{~cm}^{-1}$ were unresolved. The ornithine content of the intact lipid

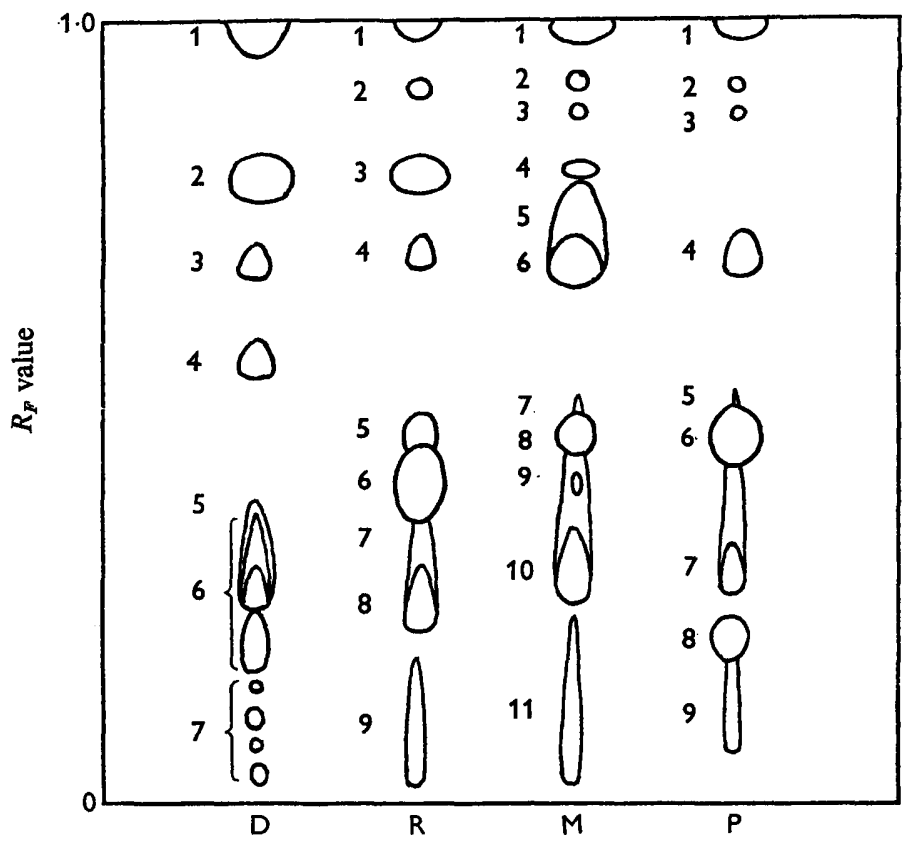

Fig. 3. Thin-layer chromatography of cell-wall extractable lipids. Drawing of a chromatogram on silica gel $\mathbf{G}$ developed with chloroform + methanol + water $(65+25+4$, by vol.). D, Pseudomonas diminuta: I, neutral lipid; 2, glycolipid; 3, fatty acid ; 4, phosphatidic acid (?); 5, phosphatidylglycerol; 6, glycolipids; 7, ninhydrin-positive components. R, Pseudomonas rubescens: I, 2, neutral lipids; 3, glycolipid; 4, fatty acid; 5, phosphatidylethanolamine; 6 , ornithine-containing lipid; 7, glycolipid; 8, phosphatidylglycerol; 9, unidentified ninhydrin-positive phospholipid. M,Pseudomonas maltophilia: 1, 2, 3, neutral lipids; 4, glycolipid; 5, cardiolipin; 6, fatty acid; 7 , unidentified phospholipid; 8, phosphatidylethanolamine; 9, ornithine-containing lipid; I0, glycolipid and phosphatidylglycerol; 11 , unidentified phospholipid. P, Pseudomonas pavonacea: 1, 2, 3, neutral lipids; 4, fatty acid; 5, unidentified phospholipid; 6 , phosphatidylethanolamine; 7 , phosphatidylglycerol : 8 , lysophosphatidylethanolamine (?); 9, unidentified phospholipid.

was $21 \%$, compared with the value of $17 \%$ found for the corresponding lipid from a Mycobacterium species (Lanéelle et al. 1963). As these authors have pointed out, these results indicate that the lipid contains two long-chain fatty residues per mole of ornithine. The analysis also indicated that the lipid constituted about $40 \%$ of the total lipid in the cell wall of $P$. rubescens. The lipid reacted with 2,4-dinitrofluorobenzene to give on hydrolysis an acid-soluble, ninhydrin-positive DNP-derivative. The derivative moved as a single spot corresponding to $\delta$-DNP-ornithine on thin-layer 
chromatography using $n$-propanol+aq. ammonia sp.gr. $0.88(7+3$, by vol.). The results obtained with two other solvent systems were similar except that the lipid derivative was split into two closely spaced spots, whereas the reference compound was not. As ornithine was the only amino acid present in the lipid these results might be explained in terms of an ionic equilibrium; a sample of $\alpha$-DNP-ornithine was not available for chromatographic comparisons.

Simple long-chain alcohols such as $n$-hexadecanol were not detected either by thinlayer or gas-liquid chromatography of material extracted by light petroleum from an acid hydrolysate of the ornithine-containing lipid, nor of the chloroform-soluble material obtained during mild alkaline hydrolysis of the crude lipid. After methylation of the material from the acid hydrolysate at least 20 components were detected by gas-liquid chromatography. Of the nine major components only the methyl esters of the straight chain $\mathrm{C}_{16}, \mathrm{C}_{16: 1}$ and $\mathrm{C}_{18: 1}$ acids were readily recognized. Further work on this lipid will be reported separately.

Lipids from Pseudomonas maltophilia. A small amount of an ornithine-containing lipid was also present in the wall of $P$. maltophilia. It had the same properties as the corresponding lipid from $P$. rubescens both on thin-layer and silicic acid column chromatography. Small or trace amounts of glycolipids, fatty acids and neutral lipids were also present. One of the neutral lipids had the mobility of a hydrocarbon on thinlayer chromatography. Of the five phospholipids in the extract, the one present in the largest amount was apparently cardiolipin. The water-soluble phosphate ester formed on mild alkaline hydrolysis had the same properties as the corresponding product from a reference sample of cardiolipin (Sylvana Chemical Co., Orange, New Jersey, U.S.A.) on high voltage electrophoresis and on paper chromatography in three solvent systems. On thin-layer chromatograms the parent lipid moved rather more slowly than the reference compound in all solvent systems tried, and its behaviour on a silicic acid column was also uncharacteristic. Whereas cardiolipin is normally the first of the common phospholipids to be eluted, only a small amount of the lipid from $P$. maltophilia was eluted using 5 and $10 \%(\mathrm{v} / \mathrm{v})$ methanol in chloroform. Most of the lipid was eluted along with phosphatidylethanolamine (M 8 in Fig. 3) using $20 \%$ (v/v) methanol, while a further amount free of phosphatidylethanolamine was only recovered using $33 \%(\mathrm{v} / \mathrm{v})$ methanol in chloroform. This result was reproduced using two different grades of silicic acid. It was similarly shown that the small amount of phosphatidylglycerol present in the extract was retarded on a column compared with the same lipid from $P$. rubescens. These findings might be most easily explained by the effects of cations on the chromatographic properties of the lipids (De Haas, Bonsen \& van Deenen, 1966), although the possibility of structural variations has to be considered (Courtade, Marinetti \& Stotz, 1967). Of the two remaining phospholipids from $P$. maltophilia at least one (M 7 in Fig. 3) may be a decomposition product of cardiolipin; it was eluted from silicic acid using $33 \%(\mathrm{v} / \mathrm{v})$ methanol in chloroform. After deacylation of a mixture of the four phospholipids of highest $R_{F}$ values, only spots corresponding to bis-(glycerophosphoryl)-glycerol, glycerophosphorylglycerol and glycerophosphorylethanolamine were detected on paper chromatography and electrophoresis. The fifth phospholipid has not been further studied.

Lipids from Pseudomonas pavonacea. As only $\mathrm{I} \cdot \mathrm{I} 6 \mathrm{mg}$. of lipid from the wall of $P$. pavonacea was obtained, extensive studies were not possible. Phosphorus analysis and thin-layer chromatography of the extract showed a high content of phospholipids, 
principally phosphatidylethanolamine. A moderate amount of phosphatidylglycerol, two unidentified phospholipids and a ninhydrin-positive phospholipid having the $\boldsymbol{R}_{\boldsymbol{F}}$ values of lysophosphatidylethanolamine were also detected. However, the possibility that the latter compound was an $O$-amino acyl ester of phosphatidylglycerol was not excluded. The other unidentified phospholipids (P 5 and $P 9$ in Fig. 3) resembled those described for $P$. maltophilia. Although cardiolipin was not detected, the substantial amount of the compound thought to be lysophosphatidylethanolamine suggested that degradation of the phospholipids of $P$. pavonacea might have been unusually extensive. A moderate amount of free fatty acid and traces of neutral lipids were also found in the extract.

\section{Material extracted from cell walls of Pseudomonas iodinum by trichloroacetic acid}

The Gram-positive character and the high phosphorus content of the cell wall of $P$. iodinum suggested that a teichoic acid might be present. To examine this possibility a larger quantity of cell walls was prepared. As with the first batch, the walls contained very little lipid $(0.6 \%)$ and very little protein relative to glycosaminopeptide. However, the phosphorus content was reduced to $\mathrm{I} \cdot 67 \%$ and more galactose than glucose was present. During extractions with trichloroacetic acid two-thirds of the total phosphorus was solubilised. Only I \% of the soluble phosphorus was estimated as inorganic orthophosphate, and none of it was extracted from aqueous solution by $n$-butyl acetate. The solid obtained on drying the crude extract contained both glucose and galactose but only traces of ninhydrin-reactive compounds. Several spots corresponding to organic monophosphates and diphosphates were detected on chromatography of an acid hydrolysate.

After purification by dialysis $20 \mathrm{mg}$. of non-diffusable material remained. It contained $4.32 \%$ phosphorus, $2.0 \%$ nitrogen and $31.6 \%$ carbohydrate (calculated as glucose although galactose was still the major sugar). After hydrolysis for $4 \mathrm{hr}$ at $105^{\circ}$ with $6 \mathrm{~N}-\mathrm{HCl}$, at least $80 \%$ of the nitrogen in the sample was recovered as ammonia; galactosamine $(0.24 \%)$ and traces of amino acids were also found. On low voltage electrophoresis the phosphorus-containing material moved as a discrete oval spot. The distance moved by the centre of the spot after $3 \mathrm{hr}$ at $0.6 \mathrm{~mA} / \mathrm{cm}$. was $5.8 \mathrm{~cm}$., compared with $\alpha$-glycerophosphate $\left(4.9 \mathrm{~cm}\right.$.) and $\alpha, \alpha^{\prime}$-glycerol diphosphate $(6 \cdot 4 \mathrm{~cm}$.). On high voltage electrophoresis the material moved as a long streak. Similarly, on paper chromatography using solvent system $X$ the material streaked forward from the origin.

After acid hydrolysis, glycerol and possibly glycerophosphate were detected; ribitol, anhydroribitol and inositol were absent. An unidentified compound was also detected in the hydrolysate. The compound gave a weak or negative reaction with alkaline $\mathrm{AgNO}_{3}$, but rather rapidly gave a yellow colour with periodate-Schiff's reagents. The compound, together with glycerol and a compound having the mobility and reactions of a hexitol, was formed on enzymic dephosphorylation of the mixture of organic phosphates formed on partial acid hydrolysis. Thus the former compound could be an anhydrohexitol (Baddiley, Buchanan \& Carss, 1957). Insufficient material was available for more conclusive studies to be made. 


\section{Extraction of cell walls with EDTA}

No specific action by EDTA was found with any of the walls from so-called resistant organisms when using conditions under which EDTA has been shown to extract a substantial proportion of the lipopolysaccharide component from the cell walls of Pseudomonas aeruginosa and $P$. alcaligenes. (Table 4). The absolute values for soluble phosphorus do not necessarily reflect sensitivity of the cell walls to the mildly alkaline buffer, as the walls differed in the ease with which they were deposited on centrifugation.

\section{Table 4. Extraction of cell-wall phosphorus by EDTA}

\begin{tabular}{|c|c|c|}
\hline \multicolumn{3}{|c|}{$\begin{array}{l}\text { Cell walls were treated with } 3.4 \mathrm{~mm} \text {-EDTA in borate buffer }(\mathrm{pH} 9 \cdot 2) \\
\text { for I hr at } 20^{\circ} \text {. Supernatant fluids were analysed after removal of in } \\
\text { centrifugation. } \\
\begin{array}{c}\text { Percentage extraction of } \\
\text { phosphorus }\end{array}\end{array}$} \\
\hline Species & $\begin{array}{l}\text { EDTA in } \\
\text { buffer }\end{array}$ & $\begin{array}{l}\text { Buffer } \\
\text { alone }\end{array}$ \\
\hline $\begin{array}{l}\text { P. diminuta } \\
P . \text { iodinum } \\
P . \text { maltophilia } \\
\text { P. pavonacea } \\
\text { P. rubescens }\end{array}$ & $\begin{array}{r}9 \cdot 4 \\
1 \cdot 8 \\
9 \cdot 8 \\
11 \cdot 4 \\
2 \cdot 3\end{array}$ & $\begin{array}{r}9 \cdot 4 \\
1 \cdot 6 \\
11 \cdot 8 \\
8 \cdot 4 \\
2 \cdot 1\end{array}$ \\
\hline
\end{tabular}

\section{DISCUSSION}

Although several wall components have remained unidentified or have been incompletely characterized, the composition of each of the species of cell wall studied has been established in broad outline and in some detail. The bacteria selected for study were originally described as being resistant to EDTA, by using as criteria for sensitivity the release of intracellular solutes and the loss of viability under the action of EDTA. The description has now been substantiated both by the failure of EDTA to extract significant amounts of phosphorus from isolated walls and by the absence from these walls of those components which appear to characterize the lipopolysaccharides of EDTA-sensitive pseudomonads. The composition of the cell wall of Pseudomonas iodinum is so distinctive that it is best discussed apart from those of the other bacteria. $P$. iodinum is a non-motile, Gram-positive or Gram-variable bacterium which has been included in the genus Pseudomonas because it produces a phenazine pigment (Tobie, I945; Gilman, I953). From studies on DNA base composition and homology, its inclusion in the genus has been considered doubtful (De Ley, Park, Tijtgat \& van Ermengem, 1966). Sneath (1960) suggested that the organism might belong to the genus Corynebacterium or to the genus Brevibacterium. The results of the present work confirm that $\boldsymbol{P}$. iodinum is misplaced in a genus of Gram-negative organisms; the cell wall contains virtually no lipid or protein. Glycosaminopeptide components and ammonia liberated on acid hydrolysis accounted for about $95 \%$ of the total nitrogen of the cell wall. If the analytical results for amino sugars are corrected for the destruction of the pure compounds which occurred under the conditions of hydrolysis (glucosamine $32 \%$, muramic acid 4I \%), the molar ratios of the glycosaminopeptide components can be calculated. The ratio glutamic acid:alanine:diaminopimelic acid:glucosamine:mura- 
mic acid becomes $I \cdot 0: I \cdot 95: 0 \cdot 93: I \cdot 04: 0 \cdot 98$, and the glycosaminopeptide content of the cell walls for which quantitative analyses have been given was $43 \%$.

The material extracted from the cell wall of Pseudomonas iodinum by trichloroacetic acid probably is, or includes, material resembling a teichoic acid. The behaviour of the material on paper chromatography, electrophoresis and on dialysis support this view. Further evidence is provided by the detection of polyols, probably including glycerol and a hexitol, after enzymic dephosphorylation of the products obtained after partial acid hydrolysis of the material. It differed from conventional teichoic acids in not being readily precipitated from aqueous solution by acetone and in the absence of alanine. Although the amount of the material present in the cell wall was variable, it occurred in all batches of walls prepared. It is likely that galactose is a component of a separate polysaccharide also extracted from walls by trichloroacetic acid. This is suggested by the fact that the relative amounts of glucose and galactose were reversed in the batch of walls with the lower phosphorus content. This view is also supported by preliminary results on a batch of walls from $P$. iodinum organisms grown in liquid culture. The material extracted by trichloroacetic acid had an enhanced phosphorus content $(8.0 \%)$ and a decreased carbohydrate content (16.6\%). Glucose, but little or no galactose, was present in an acid hydrolysate of this material. No explanation has been found for the positive reaction for 2-keto-3-deoxyaldonic acids obtained with whole walls of $P$. iodinum (Table I). However, the result is unlikely to indicate the presence of lipopolysaccharide, of which 2-keto-3-deoxyoctonic acids are characteristic components (Ellwood, I966), as in all other respects the composition of the wall of $P$. iodinum is that expected for a Gram-positive organism.

The composition of the walls of Pseudomonas diminuta, $P$. maltophilia, $P$. pavonacea and $P$. rubescens is consistent with the Gram-negative reactions of these bacteria. Each species of wall contains appreciable amounts of protein and loosely bound lipid, and correspondingly decreased amounts of glycosaminopeptide. From the analyses of diaminopimelic acid and muramic acid it appears that the wall of $P$. pavonacea has the highest (about $20 \%$ ) and that of $P$. rubescens the lowest (about $4 \%$ ) content of glycosaminopeptides. Although the amounts of walls available were insufficient for the extraction of lipopolysaccharides, there was evidence for the presence of such compounds in each species of wall. For example, the percentage of the total phosphorus of walls extracted as loosely bound lipids ranged from $17 \%$ ( $P$. rubescens) to $39 \%$ ( $P$. diminuta). The situation is least clear for $P$. diminuta. Although the wall of this organism was the only one which apparently gave reactions both for a 2-keto-3-deoxyaldonic acid and for an aldoheptose, it had a very low content of phosphorus. It was also the only wall in which analysis did not show a molar excess of glucosamine over muramic acid. Both phosphorus and glucosamine are currently accepted as basal components of bacterial lipopolysaccharides. It seems unlikely that the structure of the wall of $P$. diminuta is comparable with the structures of the other walls studied.

The walls of Pseudomonas diminuta and $P$. rubescens had particularly high lipid contents and were notable for the presence of major amounts of glycolipids and an ornithine-containing lipid, respectively. It is possible that in $P$. diminuta the structural or functional roles of phospholipids are partly taken by glycolipids. The reactions of the ornithine-containing lipid with ninhydrin and with 2,4-dinitrofluorobenzene indicate that one amino group of the ornithine (probably that in the $\delta$-position) is 
free. The natures of the residues involved in ester and amide linkages are not yet known. However, if the amino acid is not esterified with a fatty alcohol it seems that two longchain residues must be attached to the amino acid via the second amino group. The ornithine-containing lipid is a minor component of the cell wall of $P$. maltophilia. Phosphatidylcholine and phosphatidylinositol were not detected in any of the lipids; phosphatide composition has so far been of limited value in establishing taxonomic relationships between bacteria (Kates, 1964; Ikawa, I967). The wall of $P$. maltophilia is distinctive for its high content of carbohydrate and for the variety of its monosaccharide components (up to I I sugars, amino sugars and sugar acids may be present). The amount of rhamnose is so much greater than that of any other sugar that it seems likely to occur as a separate rhamnan.

Although the composition of the walls of each of the species studied is significantly different from that of Pseudomonas aeruginosa or $P$. alcaligenes, information about the more typical pseudomonads is not yet sufficiently extensive or detailed for taxonomic decisions to be made on the basis of the present results, except in the case of $P$. iodinum. Nevertheless, it may be said that the four other species bear no obvious relationship to the EDTA-sensitive pseudomonads nor to each other. As a result of studies on DNA it has been proposed that $P$. pavonacea and $P$. rubescens be omitted from the genus $P$ seudomonas, while $P$. diminuta was considered to be a doubtful member (De Ley et al. 1966). The isolated position of $P$. maltophilia relative to other aerobic pseudomonads has also been demonstrated (De Ley, 1964; Stanier, Palleroni \& Doudoroff, 1966). The results of the present studies are in accord with these findings.

I wish to thank Miss L. Galbraith for valuable technical assistance, supported by the Medical Research Council. Electron microscopic examination of cell walls was done by Mr P. Worthington and gas-liquid chromatography by Mr F. Brown. I am also grateful to Dr H. Stockdale for a reference infrared spectrum of poly- $\beta$-hydroxybutyrate, and to Dr A. Gorchein for information about the ornithine-containing lipid from Rhodopseudomonas spheroides.

\section{REFEREN CES}

Allen, R. J. L. (1940). The estimation of phosphorus. Biochem. J. 34, 858.

Asbell, M. A. \& EAGON, R. G. (1966a). The role of multivalent cations in the organization and structure of bacterial cell walls. Biochem. biophys. Res. Commun. 22, 664 .

Asbell, M. A. \& EAGON, R. G. $(1966 b)$. Role of multivalent cations in the organization, structure, and assembly of the cell wall of Pseudomonas aeruginosa. J. Bact. 92, 380.

Baddiley, J., Buchanan, J. G. \& Carss, B. (1957). A method for the identification of pentitols and hexitols. J. chem. Soc. p. 4138.

Baddiley, J., Buchanan, J. G., Handschumacher, R. E. \& Prescott, J. F. (1956). Biosynthesis of purine nucleotides. I. Preparation of $N$-glycylglycosylamines. J. chem. Soc. p. 2818.

Bartlett, G. R. (1959). Phosphorus assay in column chromatography. J. biol. Chem. 234, 466.

BOAS, N. F. (I953). Method for the determination of hexosamines in tissues. J. biol. Chem. $204,553$.

Brenner, M., Niederwieser, A. \& PATAKI, G. (196I). Dünnschicht-chromatographie von aminosäurederivaten auf kieselgel G. N-(2,4-dinitrophenyl)-aminosäuren und 3-phenyl-2-thiohydantoine. Experientia 17, 145 .

Brenner, M., Niederwieser, A. \& PATAKI, G. (1964). Characterization of protein hydrolysates and amino acids in biological materials by thin-layer chromatography. In New Biochemical Separations. Ed. by A. T. James and L. J. Morris. p. I23. London: Van Nostrand Co. Ltd.

Bryson, J. L. \& MrTChell, T. J. (I95I). Improved spraying reagents for the detection of sugars on paper chromatograms. Nature, Lond. I67, 864.

Clarke, K., Gray, G. W. \& Reaveley, D. A. (1967). The extraction of cell walls of Pseudomonas aeruginosa with aqueous phenol. The insoluble residue and material from the aqueous layers. Biochem. J. 105, 759. 
Courtade, S., Marinetti, G. V. \& Stotz, E. (1967). The structure and abundance of rat tissue cardiolipins. Biochim. biophys Acta 137, 121 .

Cynkin, M. A. \& Ashwell, G. (1960). Estimation of 3-deoxy sugars by means of the malonaldehydethiobarbituric acid reaction. Nature, Lond. 186, I55.

Dawson, R. M. C. (1960). A hydrolytic procedure for the identification and estimation of individual phospholipids in biological samples. Biochem. J. 75, 45 .

De HaAs, G. H., Bonsen, P. P. M. \& van Deenen, L. L. M. (I966). Studies on cardiolipin. III. Structural identity of ox-heart cardiolipin and synthetic diphosphatidyl glycerol. Biochim. biophys. Acta II6, I 14.

De LeY, J. (1964). Pseudomonas and related genera. A. Rev. Microbiol. 18, 17.

De Ley, J., PARK, I. W., Tijtgat, R. \& van ERmengeM, J. (1966). DNA homology and taxonomy of Pseudomonas and Xanthomonas. J. gen. Microbiol. 42, 43.

Depinto, J. A. (1967). Ornithine-containing lipid in Rhodospirillum rubrum. Biochim. biophys. Acta 144, 113.

Dische, Z. \& Shettles, L. B. (1948). A specific color reaction of methylpentoses and a spectrophotometric micromethod for their determination. J. biol. Chem. 175, 595.

DitTmer, J. C. \& LeSteR, R. L. (1964). A simple specific spray for the detection of phospholipids on thin-layer chromatograms. J. Lipid Res. 5, 126.

Dubois, M., Gilles, K. A., Hammton, J. K., Rebers, P. A. \& Smith, F. (1956). Colorimetric method for determination of sugars and related substances. Analyt. Chem. 28, 350.

Duthie, A. H. \& PATton, S. (I965). Purification of phospholipids recovered from thin-layer chromatograms for infrared spectral analysis. J. Lipid Res. 6, 320.

EAGON, R. G. \& CARSON, K. J. (I965). Lysis of cells walls and intact cells of Pseudomonas aeruginosa by ethylenediamine tetraacetic acid and by lysozyme. Can. J. Microbiol. Ir, 193.

EDWARD, J. T. \& Waldron, D. M. (1952). The detection of deoxy-sugars, glycals, and methyl pentoses in paper partition chromatography. J. chem. Soc. p. 3631 .

Ellwood, D. C. (1966). The distribution of 3-deoxy-2-oxo-sugar acids in the cell walls of Gramnegative bacteria. Biochem. J. 99, 55 P.

FISCHER, F. G. \& NEBEL, H. J. (1955). Qualitative and quantitative estimation of glucosamine and galactosamine by the method of paper chromatography. Hoppe-Seyl. Z. 302, 10.

GilmaN, J. P. (1953). Studies on certain species of bacteria assigned to the genus Chromobacterium. J. Bact. 65, 48.

Goldschmid, M. C. \& WYSs, O. (1967). The role of tris in EDTA toxicity and lysozyme lysis. J. gen. Microbiol. 47, 42 I.

GorcheIN, A. (1964). Ornithine in Rhodopseudomonas spheroides. Biochim. biophys. Acta 84, 356.

GraY, G. W. \& WILKInson, S. G. (1965a). The action of ethylenediaminetetra-acetic acid on Pseudomonas aeruginosa. J. appl. Bact. 28, 153.

GraY, G. W. \& WiLkInson, S. G. (I965 b). The effect of ethylenediaminetetra-acetic acid on the cell walls of some Gram-negative bacteria. J. gen. Microbiol. 39, 385 .

HANeS, C. S. \& Isherwood, F. A. (I949). Separation of the phosphoric esters on the filter paper chromatogram. Nature, Lond. 164 , 1107.

IKAWA, M. (1967). Bacterial phosphatides and natural relationships. Bact. Rev. 3r, 54 .

Ikawa, M., Morrow, J. W. \& Harney, S. J. (I966). Paper chromatographic system for the identification of glycerol in bacterial cell walls. J. Bact. $92,812$.

KÄrKKÄInEN, J., LeHTONEN, A. \& NikKarI. T. (1965). Determination of glucosamine and galactosamine by gas chromatography. $J$. Chromat. $20,457$.

KATES, M. (1964). Bacterial lipids. Adv. Lipid Res. 2, 17.

Lanéelle, M.-A., Lanéelle, G. \& Asselineau, J. (I963). Sur la présence d'ornithine dans des lipides bactériens. Biochim. biophys Acta 70, 99.

LEIVE, L. (1965). Release of lipopolysaccharide by EDTA treatment of E. coli. Biochim. biophys. Res. Commun. 2r, 290.

MACGREgor, D. R. \& Elliker, P. R. (1958). A comparison of some properties of strains of Pseudomonas aeruginosa sensitive and resistant to quaternary ammonium compounds. Can.J. Microbiol. 4, 499.

MaRUo, B. \& Benson, A. A. (1959). Cyclic glycerophosphate formation from the glycerolphosphatides. J. biol. Chem. 234, 254 .

Morrison, W. R. \& SMith, L. M. (1964). Preparation of fatty acid methyl esters and dimethylacetals from lipids with boron fluoride-methanol. J. Lipid Res. 5, 600.

MukerJee, H. \& RAM, J. S. (1964). Paper chromatographic separation of glucosamine and galactosamine. Analyt. Biochem. 8, 393.

Nichols, B. W. (1964). Separation of plant phospholipids and glycolipids. In New Biochemical Separations. Ed. by A. T. James and L. J. Morris. p. 32I. London: Van Nostrand Co. Ltd. 
OSBORN, M. J. (1963). Studies on the Gram-negative cell wall. I. Evidence for the role of 2-keto-3deoxyoctonate in the lipopolysaccharide of Salmonella typhimurium. Proc. natn. Acad. Sci., U.S.A. 50, 499.

Pataki, G. (1967). Thin-layer chromatography of amino acids. Chromat. Rev. 9, 23.

Perkins, H. R. \& Cummins, C. S. (1964). Ornithine and 2,4-diaminobutyric acid as components of the cell walls of plant pathogenic Corynebacteria. Nature, Lond. 20r, I 105.

Radhakrishnamurthy, B., Dalferes, E. R. \& Berenson, G. S. (I966). Determination of hexosamines by gas-liquid chromatography. Analyt. Biochem. 17, 545 .

Rouser, G., Kritchevsky, G., Heller, D. \& Lieber, E. (I963). Lipid composition of beef brain, beef liver, and the sea anemone: two approaches to quantitative fractionation of complex lipid mixtures. J. Amer. Oil Chem. Soc. 40, 425.

Shively, J. M. \& HARTSELl, S. E. (1964). Bacteriolysis of the pseudomonads. I. Agents potentiating lysis. Can. J. Microbiol. 10, 905.

SkIPSKI, V. P., Barclay, M., Reichman, E. S. \& Good, J. J. (I967). Separation of acidic phospholipids by one-dimensional thin-layer chromatography. Biochim. biophys. Acta $\mathbf{1 3 7}, 80$.

SkIPSki, V. P., Peterson, R. F., SANDERS, J. \& BARClay, M. (1963). Thin-layer chromatography of phospholipids using silica gel without calcium sulphate binder. J. Lipid Res. 4, 227.

SkiPSKI, V. P., Smolowe, A. F., Sullivan, R. C. \& Barclay, M. (I965). Separation of lipid classes by thin-layer chromatography. Biochim. biophys. Acta ro6, 386.

SNeAth, P. H. A. (1960). A study of the bacterial genus Chromobacterium. Iowa St. J. Sci. 34, 429.

Stanier, R. Y., PAlleroni, N. J. \& Doudoroff, M. (1966). The aerobic pseudomonads: a taxonomic study. J. gen. Microbiol. 43, 159.

StoffYN, P. J. \& JeAnloz, R. W. (I954). Hyaluronic acid and related substances. XII. Identification of amino sugars by paper chromatography. Arch. Biochem. 52, 373.

Sweeley, C. C., Bentley, R., Makita, M. \& Wells, W. W. (1963). Gas-liquid chromatography of trimethyl silyl derivatives of sugars and related substances. J. Am. chem. Soc. 85, 2497.

ToвIE, W. C. (1945). A proposed biochemical basis for the genus Pseudomonas. J. Bact. 49, 459.

Trevelyan, W. E., Proctor, D. P. \& Harrison, J. S. (1950). Detection of sugars on paper chromatograms. Nature, Lond. 166, 444.

Umbreit, W. W., Burris, R. H. \& Stauffer, J. F. (1957). Manometric Techniques, 3rd ed., p. 274. Minneapolis: Burgess Publishing Co.

Vincent, J. M., Humphrey, B. \& NorTh, R. J. (1962). Some features of the fine structure and chemical composition of Rhizobium trifiolii. J. gen. Microbiol. 29, 55 I.

Voss, J. G. (1967). Effects of organic cations on the Gram-negative cell wall and their bactericidal activity with ethylenediamine-tetra-acetate and surface active agents. J. gen. Microbiol. 48, $39 \mathrm{I}$.

WAGNER, H., Hörhammer, L. \& WOLFF, P. (I96I). Dünnschichtchromatographie von phosphatiden und glykolipiden. Biochem. Z. 334, 175 .

WARREN, L. (I960). Thiobarbituric acid spray reagent for deoxy sugars and sialic acids. Nature, Lond. 186, 237.

WestPhal, O. \& LÜDERITZ, O. (1960). 3,6-Dideoxy-hexosen-Chemie und Biologie. Angew. Chem. 72, 881 .

WheEldon, L. W. \& Collins, F. D. (I957). Studies on phospholipids. I. The determination of amino nitrogen in unhydrolysed phospholipids. Biochem. J. 66, 435.

WilkInson, S. G. (1967). The sensitivity of pseudomonads to ethylene-diaminetetra-acetic acid. J. gen. Microbiol. 47, 67.

WILKINSON, S. G. (1968). Glycolipids containing glucose and uronic acids in Pseudomonas species. Biochim. biophys. Acta 152, 227.

Wolin, M. J. (I966). Lysis of Vibrio succinogenes by ethylenediamine-tetraacetic acid or lysozyme. J. Bact. 91, $178 \mathrm{I}$.

WoRK, E. (1957). Reaction of ninhydrin in acid solution with straight-chain amino acids containing two amino groups and its application to the estimation of $\alpha \epsilon$-diaminopimelic acid. Biochem.J. $67,416$.

YouNG, D. A. B. (1964). Use of butyl acetate as a solvent for the extraction of trichloroacetic acid. Biochim. biophys. Acta $90,178$.

ZIMmíski, T. \& BoRowski, E. (1966). A new spray reagent replacing sulphuric acid in thin-layer chromatography. J. Chromat. 23, 480 . 